Original Paper

\title{
Upaya Meningkatkan Aktivitas dan Hasil Belajar Fisika Siswa Menggunakan Model Pembelajaran Quching
}

\author{
Muhammad Multazam ${ }^{1^{*}}$ \\ ${ }^{1}$ Sekolah Menengah Atas Negeri 4 Praya, Lombok Tengah, Nusa Tenggara Barat, Indonesia
}

*Corresponding Author:

Muhammad Multazam,

Sekolah Menengah Atas

Negeri 4 Praya, Lombok

Tengah, Nusa Tenggara

Barat, Indonesia.

Email:

multazammuh1971@gmail.com

\begin{abstract}
Abstrak: Penelitian tindakan kelas ini bertujuan untuk meningkatkan aktivitas dan hasil belajar fisika siswa kelas X-MIPA-2 SMA Negeri 4 Praya dengan menggunakan model pembelajaran Quantum Teaching (Quching) pada materi Gerak Lurus. Penelitian ini dilaksanakan dalam tiga siklus yaitu siklus I, siklus II, dan siklus III. Tiap siklus terdiri dari perencanaan tindakan, pelaksanaan tindakan, observasi, dan refleksi. Instrumen yang digunakan adalah lembar observasi aktivitas siswa, lembar observasi kegiatan guru, dan tes hasil belajar dengan soal pilihan ganda. Teknik analisis data yang digunakan yaitu analisis data deskriptif kuantitatif dan kualitatif. Hasil penelitian menunjukkan adanya peningkatan aktivitas dan hasil belajar fisika siswa pada tiap siklus. Pada siklus I, pembelajaran siswa belum berjalan dengan baik sehingga hasil belajar siswa masih rendah yaitu 66,12 dengan jumlah siswa yang berhasil sebanyak 15 orang dan rata-rata aktivitas yang diperoleh seluruh siswa adalah 48,10\%. Hal ini disebabkan karena guru belum sepenuhnya menguasai model pembelajaran. Pada siklus II nilai rata-rata hasil belajar 77,2 dan rata-rata persentase aktivitas siswa meningkat menjadi $61,66 \%$ dan dengan jumlah siswa yang berhasil sebanyak 18 orang. Pada siklus III nilai rata-rata hasil belajar 81,00 dan ratarata persentase aktivitas siswa meningkat menjadi $73,56 \%$ dengan jumlah siswa yang berhasil sebanyak 29 orang. Berdasarkan hasil yang diperoleh dalam penelitian dapat disimpulkan bahwa dengan menggunakan model pembelajaran Quantum Teaching dapat meningkatkan nilai hasil belajar fisika dan aktivitas siswa di kelas X-MIPA-2.
\end{abstract}

Kata kunci: Aktivitas, Hasil Belajar, Model Pembelajaran Quantum Teaching.

\section{Pendahuluan}

Fisika merupakan salah satu mata pelajaran yang telah diperkenalkan kepada siswa sejak sekolah dasar hingga perguruan tinggi. Akan tetapi, pada kenyataannya pelajaran fisika kurang diminati siswa pada umumnya, karena dianggap sulit, sehingga proses pembelajaran fisika tidak sesuai seperti yang diharapkan. Masalah siswa dalam belajar di kelas salah satunya adalah kurang memahami konsep materi pelajaran. Kesulitan itu kemudian yang menyebabkan kurangnya minat siswa terhadap mata pelajaran fisika. Hal ini yang menyebabkan aktivitas siswa dalam mengikuti pembelajaran fisika di kelas menjadi rendah. Proses belajar mengajar dapat terlaksana dengan baik apabila terdapat interaksi yang baik antara guru dan siswa. Agar tercipta interaksi tersebut maka dibutuhkan pembelajaran yang dapat 
melibatkan aktivitas siswa. Dengan adanya pembelajaran yang melibatkan aktivitas siswa, diharapkan siswa dapat memahami konsep pembelajaran yang diajarkan oleh guru.

Dari hasil ulangan harian mata pelajaran fisika di sekolah diperoleh data bahwa rendahnya hasil belajar fisika siswa kelas XMIPA-2 ini disebabkan oleh siswa yang tidak mengerjakan tugas-tugas yang diberikan guru, siswa tidak memperhatikan guru saat guru menjelaskan materi, siswa muda lupa dengan materi pelajaran yang sudah diajarka oleh guru, siswa masih banyak yang ribut saat pembelajaran berlangsung. Salah satu pendekatan pembelajaran yang menarik yang dapat meningkatkan aktivitas belajar siswa adalah pendekatan pembelajaran Quantum Teaching (Quching).

Model Quching merupakan cara baru yang memudahkan proses belajar, yang memadukan unsur seni dan pencapaian terarah untuk segala mata pelajaran dengan menggabungkan keistimewaan-keistimewaan belajar menuju bentuk perencanaan pengajaran yang akan melejitkan prestasi siswa (Wena, 2013: 160). Model Quching adalah pengubahan belajar yang meriah dengan segala nuansanya yang menyertakan segala kaitan, interaksi, dan perbedaan yang memaksimalkan momen belajar serta berfokus pada hubungan dinamis dalam lingkungan kelas interaksi yang mendirikan landasan dalam rangka untuk belajar (De Porter, 2005: 8-9).

Aktivitas merupakan prinsip utama yang sangat penting didalam interaksi belajar mengajar dan indikator adanya keinginan siswa untuk belajar. Aktivitas artinya kegiatan atau keaktifan (Djamarah, 2008). Jadi segala sesuatu yang dilakukan atau kegiatankegiatan yang terjadi baik fisik maupun nonfisik, merupakan suatu aktivitas.

Aktivitas siswa selama proses belajar mengajar merupakan salah satu indikator adanya keinginan siswa untuk belajar. Terdapat 9 aspek untuk menumbuhkan aktivitas dan partisipasi siswa pada kegiatan pembelajaran yang dilakukan di dalam kelas yaitu: 1) Memberikan motivasi atau menarik perhatian siswa, sehingga mereka berperan aktif dalam kegiatan pembelajaran. 2) Menjelaskan tujuan intruksional (kemampuan dasar) kepada siswa. 3) Mengingatkan kompetensi prasyarat. 4) Memberikan stimulus (masalah, topik, dan konsep) yang akan dipelajari. 5) Memberi petunjuk kepada siswa cara mempelajarinya. 6) Memunculkan aktivitas, partisipasi siswa dalam kegiatan pembelajaran. 7) Memberikan umpan balik (feed back). 8) Melakukan tagihan-tagihan terhadap siswa berupa tes, sehingga kemampuan siswa selalu terpantau dan terukur. 9) Menyimpulkan setiap materi yang disampaikan pada akhir pembelajaran (Gagne dan Briggs dalam Handayani, 2014).

Sesuai dengan masalah yang diteliti, maka tujuan penelitian ini adalah untuk meningkatkan aktivitas dan hasil belajar fisika siswa dengan menggunakan model pembelajaran Quching pada materi gerak lurus. Manfaat dari penelitian ini yaitu 1) Sebagai gambaran bagi guru dalam penerapan model pembelajaran Quching pada proses pembelajaran di kelas. 2) Diharapkan melalui penerapan model pembelajaran Quching dapat menigkatkan aktivitas dan hasil belajar fisika. 3) Untuk menambah pengetahuan dan pengalaman dalam menerapkan model pembelajaran Quching.

\section{Metode}

Jenis penelitian ini adalah Penelitian Tindakan Kelas (Classroom Action Research), yang merupakan upaya yang dilakukan guru untuk meningkatkan kualitas peran dan tanggung jawab guru khususnya dalam pengelolaan pembelajaran (Sanjaya, 2011:13). Penelitian ini terdiri dari 3 siklus. Pada setiap siklus memiliki tahapan-tahapan tertentu sesuai dengan tahapan dalam tindakan kelas yaitu perencanaan tindakan, pelaksanaan tindakan, observasi, refleksi. Adapun 
rancangan siklus pada penelitian tindakan kelas (Arikunto, 2007:16) yang dilakukan dari awal hingga akhir dapat dilihat pada Gambar 1:

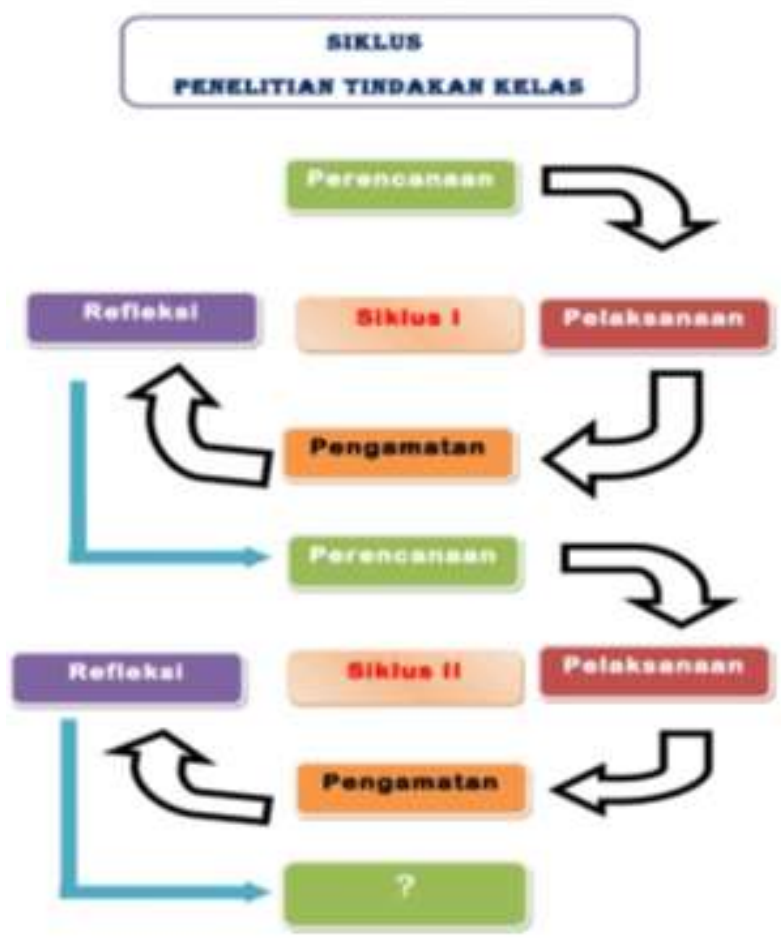

Gambar 1. Rancangan Siklus Pada Penelitian Tindakan Kelas

Penelitian ini dilaksanakan di SMA Negeri 4 Praya Lombok Tengah. Waktu penelitian tindakan kelas ini dilaksanakan semester ganjil Tahun Pelajaran 2017/2018 pada bulan Juli-September 2017. Subjek penelitian ini adalah siswa kelas X-MIPA-2 SMA Negeri 4 Praya Lombok Tengah dengan jumlah sebanyak 32 orang siswa yang terdiri dari 11 siswa laki-laki dan 21 siswa perempuan. Jenis data yang diambil dalam penelitian ini berupa data kualitatif yang terdiri atas data tentang aktivitas siswa dan guru dalam proses belajar mengajar, dan data kuantitatif yaitu data tentang hasil belajar siswa setiap akhir siklus.

Pengambilan data kualitatif dilakukan dengan menggunakan lembar pengamatan aktivitas siswa dan lembar pangamatan kegiatan guru. Sedangkan pengambilan data kuantitatif dilakukan dengan menggunakan seperangkat alat tes (Ulangan Formatif) berupa tes obyektif yang diadakan setiap akhir siklus pembelajaran.

Dalam penelitian ini digunakan instrumen tes berupa tes objektif dengan alternatif pilihan yang memenuhi syarat standar soal yaitu validitas, tingkat kesukaran tiap soal, daya pembeda dan reliabilitas yang memenuhi kriteria tertentu. Pada lembar aktivitas siswa terdapat sederetan aktivitas siswa yang diamati oleh pengamat sebagai observer. Aktivitas siswa yang diamati dan disusun sesuai dengan variabel yang dibuat berdasarkan sintak pembelajaran yang ada di RPP. Lembar observasi aktivitas siswa dalam bentuk angka dengan total nilai berupa persen.

Pada penelitian ini dilakukan observasi proses pembelajaran dengan menggunakan model pembelajaran Quching terhadap guru. Lembar observasi kegiatan guru dibuat berdasarkan sintak-sintak model pembelajaran yang ada di rencana pelaksanaan pembelajaran (RPP). Pengamat untuk observasi kegiatan guru dilakukan oleh guru sejawat mata pelajaran fisika di SMA Negeri 4 Praya. Lembar observasi kegiatan guru dalam bentuk cheklis dengan menggunakan skala likert. Pengisian lembar observasi kegiatan guru dilaksanakan dipertemuan kedua tiap siklus.

Data kualitatif diambil dari data hasil observasi tentang situasi belajar mengajar, yaitu untuk data hasil observasi aktivitas siswa dihitung dengan menggunakan persamaan:

\section{$\mathrm{A}=\underline{\mathrm{Na}} \times 100 \%$}

Keterangan:

A = Aktifitas siswa

$\mathrm{Na} \quad=$ Jumlah siswa yang aktif

$\mathrm{N} \quad=$ Jumlah siswa keseluruhan

Dengan perhitungan penilaiannya:

0-20 = Tidak Aktif

21-40 = Kurang Aktif 
41-60 = Cukup Aktif

61-80 = Aktif

81-100 = Sangat Aktif

Untuk lembar observasi siswa ditentukan angka rata-ratanya kemudian dicocokkan dengan kategori. Angka-angka tersebut digunakan sebagai tolak ukur yang menunjukkan kualitas siswa selama proses pembelajaran. Sedangkan data untuk hasil lembaran observasi guru dihitung dengan menjumlahkan seluruh data sesuai dengan kriteria yang telah ditentukan.

Proses perhitungan data hasil belajar siswa diperoleh dari pemberian tes tulis pada tahap evaluasi, dimana soal-soal berbentuk objektif dengan lima alternatif pilihan. Untuk menganalisis data digunakan rumus yang dikemukakan oleh Sudijono (2008).

$S=\sum\left(R-\frac{W}{n-1}\right) \mathrm{xWt}$

Keterangan:

$\mathrm{S} \quad=$ Skor

$\mathrm{R} \quad$ = Jumlah jawaban yang benar

$\mathrm{W}=$ Jumlah jawaban yang salah

$\mathrm{Wt}=$ Bobot

$\mathrm{N} \quad=$ Jumlah option

Instrument yang digunakan untuk mengumpulkan data penilaian sikap berupa lembar observasi yang diperoleh dari hasil pengamatan terhadap proses sikap tertentu sepanjang proses pembelajaran. Perhitungan nilai sikap dan keterampilan adalah (Kurniasih, 2014):

\section{Nilai $=$ skormentah $\quad x 100 \%$ Skormaksimum}

\section{Hasil dan Pembahasan}

\section{Siklus I}

Siklus I merupakan pelaksanaan tindakan awal yang dilakukan pada pelaksanaan penelitian tindakan kelas. Pada siklus I, pelaksanaan tindakan dilakukan dua kali pertemuan dan satu kali ujian siklus. Pada setiap pertemuan masing-masing terdiri dari dua jam pelajaran berdurasi selama 45 menit. Pertemuan pertama siklus I materi yang diajarkan mengenai konsep usaha. Sedangkan, pada pertemuan kedua siklus I dilanjutkan dengan materi energi potensial dan energi kinetik.

Langkah-langkah pelaksanaan proses pembelajaran disesuaikan dengan rencana pelaksanaan pembelajaran (RPP) dengan menggunakan model pembelajaran Quching. Langkah-langkah penelitian pada siklus I ini sesuai dengan rencana pelaksanaan pembelajaran I dengan menggunakan model pembelajaran Quching. Pada awal pembelajaran guru membuka pelajaran, mengucapkan salam dan memeriksa kehadiran siswa. Kemudian guru memberikan apersepsi dan motivasi kepada siswa dengan pertanyaanpertanyaan tentang materi yang akan diajarkan.

Dilanjutkan dengan menyampaikan tujuan pembelajaran yang akan dicapai, guru membagi kelompok dan lembar kerja siswa yang akan digunakan pada pertemuan ini. Kemudian guru melakukan langkah-langkah dalam penerapan model quantum teaching seperti: (1) menumbuhkan minat belajar siswa untuk mengikuti pembelajaran (tumbuhkan); (2) memfasilitasi siswa untuk mendapatkan pengalaman belajar dengan percobaan (alami); (3) membimbing siswa untuk menarik kesimpulan berdasarkan informasi, fakta atau rumus yang ditemukan (namai); (4) memberi kesempatan kepada siswa untuk memaparkan hasil percobaan yang telah dilakukan (demonstrasi); (5) mengarahkan siswa untuk mengulangi pengetahuan yang telah dimiliki ke dalam suatu persoalan supaya memperkuat koneksi saraf dalam pemahaman konsep (ulangi); dan (6) memberikan perayaan sebagai feedback positif terhadap usaha siswa selama proses pembelajaran (rayakan).

Setelah melakukan dua kali pertemuan pada pertemuan terakhir untuk siklus I, siswa diberikan tes dalam bentuk ulangan formatif 
untuk mengetahui penguasaan siswa terhadap materi pembelajaran yang telah disampaikan. Tes yang diberikan ini terdiri dari 10 butir soal pilihan ganda yang terkait dengan materi usaha dan energi. Kemudian dikuatkan kembali oleh lembar observasi guru dan lembar aktivitas siswa dalam mengikuti proses pembelajaran menggunakan model pembelajaran guided inquiry. Soal-soal tes ini sebelumnya telah dianalisis melalui uji validitas, reliabilitas, daya beda serta tingkat kesukaran. Adapun hasil belajar siswa pada siklus I dapat dillihat pada Tabel 1:

Tabel 1. Hasil Belajar Siklus I

\begin{tabular}{llll}
\hline No. & Variabel & Jumlah & Persentase \\
\hline 1 & Jumlah siswa & 32 & $100 \%$ \\
2 & Nilai rata-rata siswa & 66,12 & - \\
3 & $\begin{array}{l}\text { Jumlah siswa yang } \\
\text { berhasil }\end{array}$ & 15 & $46,88 \%$ \\
4 & $\begin{array}{l}\text { Jumlah siswa yang } \\
\text { tidak berhasil }\end{array}$ & 17 & $53,13 \%$ \\
\hline
\end{tabular}

Berdasarkan Tabel 1, dapat diketahui bahwa hasil belajar yang diperoleh siswa pada aspek pengetahuan dalam pelaksanaan tindakan siklus I ini masih rendah. Pada Tabel 1 ditunjukkan bahwa dari 32 orang siswa $(100 \%)$ yang mengikuti tes, jumlah siswa yang nilainya berada diatas Kriteria Ketuntasan Minimum (KKM), yaitu $\geq 71$ sebanyak 15 orang atau $46,88 \%$. Pada siklus I ini nilai tertinggi dari keseluruhan siswa adalah 86 dan nilai terendah adalah 55 . Nilai rata-rata siswa masih rendah yaitu 66,12. Hal ini disebabkan karena guru belum mampu menciptakan sesuatu yang menarik diawal pembelajaran, masih terdapat siswa yang kurang memperhatikan pelajaran, serta siswa yang masih banyak bermain dan ngobrol saat guru menjelaskan pelajaran.Solusinya yaitu dengan memberikan apersepsi dan motivasi yang menarik diawal pembelajaran dan menggunakan bantuan power pointdalam menyampaikan materi untuk membuat siswa memperhatikan guru saat menjelaskan materi.

Hasil aktivitas belajar siswa yang diperoleh, dapat disimpulkan bahwa pada siklus I siswa belum ada keaktifan belajar terhadap pelajaran fisika, ini terlihat dari ratarata aktivitas belajar siswa yaitu $48,10 \%$. Artinya bahwa siswa di kelas tersebut berada pada kategori cukup aktif. Pada siklus I proses pembelajaran belum terlaksana dengan baik, aktivitas siswa yang teramati belum sesuai dengan yang diharapkan. Akibatnya masih kurangnya minat siswa dalam proses pembelajaran tersebut dan hasil belajar siswa menjadi rendah. Untuk itu perlu adanya tindakan lanjutan dalam usaha untuk meningkatkan minat siswa dalam kegiatan pembelajaran yaitu pelaksanaan pembelajaran siklus II.

\section{Siklus II}

Pelaksanaan tindakan yang dilakukan pada siklus II terdiri dari dua kali pertemuan. Pertemuan pertama mengenai gerak lurus dengan kecepatan konstan, sedangkan pada pertemuan kedua mengenai gerak lurus dengan percepatan konstan.

Langkah-langkah tindakan pada siklus II ini dilakukan sesuai dengan rencana pelaksanaan pembelajaran I sampai rencana pelaksanaan pembelajaran II dengan menggunakan sintak model pembelajaran Quching. Langkah-langkah pembelajaran yang berlangsung pada siklus II sesuai dengan rencana proses pembelajaran ketiga dan keempat. Sebelum pembelajaran dimulai guru mengkondisikan agar siswa siap memulai pembelajaran. Kemudian guru mengucapakan salam dan dilanjutkan dengan memeriksa kehadiran siswa. Untuk meningkatkan aktivitas dalam menjawab pertanyaan, guru memberikan motivasi dengan memberikan reward kepada siswa yang aktif menjawab pertanyaan, mengajukan pertanyaaan dan siswa yang tertib pada saat pembelajaran berlangsung. Pertanyaan-pertanyaan yang diberikan guru berupa pertanyaan berdasarkan pada pengalaman siswa. Kemudian guru menjelaskan tujuan pembelajaran yang akan dicapai dan membagikan LKS yang akan digunakan siswa dalam pembelajaran. 
Pada akhir pembelajaran guru dan siswa menyimpulkan dari seluruh kegiatan yang dilakukan. Setelah membuat kesimpulan, pada pertemuan terakhir siklus, diadakan evaluasi siklus II untuk mengetahui penguasaan siswa pada materi yang telah diajarkan. Evaluasi siklus II ini terdiri dari 11 soal pilian ganda yang berkaitan dengan materi yang telah dipelajari.

Tabel 2. Hasil Belajar Siklus II

\begin{tabular}{llll}
\hline No. & Variabel & Jumlah & Persentase \\
\hline 1 & Jumlah siswa & 32 & $100 \%$ \\
2 & Nilai rata-rata siswa & 77,36 & - \\
3 & $\begin{array}{l}\text { Jumlah siswa yang } \\
\text { berhasil }\end{array}$ & 18 & $56,25 \%$ \\
4 & $\begin{array}{l}\text { Jumlah siswa yang } \\
\text { tidak berhasil }\end{array}$ & 14 & $43,75 \%$ \\
\hline
\end{tabular}

Berdasarkan Tabel 2, dapat diketahui bahwa pelaksanaan tindakan pada sikus II sudah mengalami peningkatan dari siklus I. Hal ini terlihat dari hasil belajar siklus II yang diikuti 32 siswa yang memperoleh nilai ratarata hasil belajar siswa meningkat dari 66,12 pada siklus I menjadi 77,36 pada siklus II. Nilai tertinggi dari seluruh siswa 87 dan nilai terendah 53. Jumlah siswa yang memperoleh nilai $\geq 75$ sebanyak 18 siswa, ini berarti keberhasilan telah mencapai $56,25 \%$ dan siswa yang belum berhasil hanya $43,75 \%$.

Dilihat dari keberhasilan yang dicapai pada siklus II mengalami peningkatan dari siklus I, tapi belum mencapai kriteria indikator yang telah ditetapkan yaitu $80 \%$ dari jumlah keseluruhan siswa yang memperoleh nilai $\geq 75$ Kendala yang masih ditemukan yaitu siswa masih melakukan aktivitas lain pada saat proses pembelajaran serta manejemen waktu yang masih kurang baik. Solusinya yaitu guru menegur beberapa siswa yang melakukan aktivitas lain dan menggunakan beberapa media seperti power point dan video pembelajaran untuk menghemat waktu saat menyampaikan materi pelajaran.

Hasil aktivitas belajar siswa yang diperoleh, dapat disimpulkan bahwa siswa pada siklus II juga masih belum ada keaktifan belajar terhadap pelajaran fisika, ini terlihat dari rata-rata aktivitas belajar siswa yaitu $61,66 \%$ ini berarti siswa di kelas tersebut berada pada kategori cukup aktif.

Pada siklus II proses pembelajaran sudah terjadi perubahan yang baik dari proses pembelajaran di siklus I. Ini berarti minat siswa dalam belajar semakin meningkat dan upaya meningkatkan minat dan hasil belajar fisika siswa dapat terlaksana dengan baik walaupun belum memiliki hasil yang memuaskan.Untuk itu perlu adanya tindakan lanjutan dalam usaha untuk meningkatkan minat siswa dalam kegiatan pembelajaran yaitu pelaksanaan pembelajaran siklus III.

\section{Siklus III}

Pelaksanaan tindakan yang dilakukan pada siklus III sama halnya dengan pelaksanaan tindakan pada siklus I dan siklus II, terdiri dari dua kali pertemuan. Pertemuan pertama mengenai gerak lurus dengan kecepatan konstan, sedangkan pada pertemuan kedua mengenai gerak lurus dengan percepatan konstan. Langkah-langkah tindakan siklus II ini dilakukan sesuai dengan rencana pelaksanaan pembelajaran I pertemuan kelima sampai rencana pembelajaran II pertemuan keenam.

Siklus III merupakan lanjutan dan perbaikan dari siklus I dan siklus II. Proses pembelajaran yang dilakukan brdasarkan hasil refleksi tindakan pada siklus II, dimana masih terdapat beberapa kegiatan yang belum terlaksana dengan baik. Tindakan yang dilakukan pada siklu III adalah sebelum pembelajaran dimulai guru mengkondisikan agar siswa siap memulai pembelajaran, kemudian guru mengucapakan salam dan dilanjutkan dengan memeriksa kehadiran siswa. Untuk meningkatkan aktivitas dalam menjawab pertanyaan, guru memberikan motivasi dengan memberikan reward kepada siswa yang aktif menjawab pertanyaan, mengajukan pertanyaaan dan siswa yang tertib pada saat pembelajaran berlangsung. Pertanyaan-pertanyaan yang diberikan guru berupa pertanyaan berdasarkan pada 
pengalaman siswa, kemudian guru menjelaskan tujuan pembelajaran yang akan dicapai dan membagikan LKS yang akan digunakan siswa dalam pembelajaran.

Pada akhir pembelajaran guru dan siswa menyimpulkan dari seluruh kegiatan yang dilakukan. Setelah membuat kesimpulan, pada pertemuan terakhir siklus, diadakan evaluasi siklus III untuk mengetahui penguasaan siswa pada materi yang telah diajarkan. Evaluasi siklus III ini terdiri dari 20 soal pilihan ganda yang berkaitan dengan materi yang telah dipelajari. Hasil belajar yang diperoleh siswa dari tes hasil belajar pada siklus III dapat dilihat pada Tabel 3 .

Tabel 3. Hasil Belajar Siklus III

\begin{tabular}{llll}
\hline No. & Variabel & Jumlah & Persentase \\
\hline 1 & Jumlah siswa & 32 & $100 \%$ \\
2 & Nilai rata-rata siswa & 81,00 & - \\
3 & $\begin{array}{l}\text { Jumlah siswa yang } \\
\text { berhasil }\end{array}$ & 29 & $91,00 \%$ \\
4 & $\begin{array}{l}\text { Jumlah siswa yang } \\
\text { tidak berhasil }\end{array}$ & 3 & $9,38 \%$ \\
\hline
\end{tabular}

Berdasarkan Tabel 3, dapat diketahui bahwa pelaksanaan pada siklus III sudah mengalami peningkatan keberhasilan pembelajaran. Hal ini dapat terlihat dari hasil belajar siklus III yang diikuti oleh 32 siswa yang memperoleh nilai rata-rata dari 77.36 pada siklus II menjadi 81,00 pada siklus III yang sekaligus menunjukkan bahwa nilai ratarata siswa telah berada diatas kriteria ketuntasan minimum (KKM), yaitu 75 dan telah mencapai $80 \%$ berada di atas persentase siswa yang berhasil dalam belajar sebesar $75 \%$. Pada siklus III nilai tertinggi yang diperoleh dari seluruh siswa adalah 96 dan nilai terendah adalah 51,95. Jumlah siswa pada siklus III yang memperoleh nilai > 75 juga lebih banyak dari siklus sebelumnya yaitu sebanyak 29 siswa atau sebesar 91,00\%. Angka keberhasilan ini menunjukkan bahwa tindakan yang dilakukan telah berhasil dan tidak perlu dilanjutkan lagi pada siklus berikutnya. Berdasarkan aktivitas belajar siswa terhadap pelajaran fisika yang telah di dapatkan, pada siklus III terjadi peningkatan yaitu rata-rata aktivitas belajar siswa yaitu $73,56 \%$ ini berarti siswa di kelas tersebut berada pada kategori aktif.

Pada siklus III proses pembelajaran sudah terjadi perubahan yang baik dari proses pembelajaran di siklus II. Ini berarti aktivitas siswa dalam belajar semakin meningkat dan upaya meningkatkan keaktifan dan hasil belajar fisika siswa dapat terlaksana dengan baik.

\section{Kesimpulan}

Berdasarkan hasil penelitian dapat disimpulkan bahwa dengan menggunakan model pembelajaran Quantum Teaching dapat meningkatkan nilai hasil belajar fisika dan aktivitas siswa di kelas X-MIPA-2 SMA Negeri 4 Praya Lombok Tengah.

\section{Daftar Pustaka}

Arikunto, S. (2007). Penelitian Tindakan Kelas. Jakarta: Bumi Aksara.

De Porter, B. dan Hernacki, M. (2013). Quantum Learning: Membiasakan Belajar Nyaman dan Menyenangkan. Bandung: Kaifa Learning.

Djamarah, S.B. (2008). Psikologi Belajar Edisi 2. Jakarta: Rineka Cipta.

Handayani, N.L.E.S., dan Perdata, I.B.K. 2014. Meningkatkan Aktivitas Dan Prestasi Belajar Siswa Melalui Penerapan Model Pembelajaran QT dengan Kerangka TANDUR dalam Pembelajaran Bangun Segi Empat Pada Siswa Kelas VII C SMP Pancasila Canggu Tahun Pelajaran 2011/2012. Jurnal Santiaji Pendidikan, 4 (1): 87-97

Kurniasih, S. (2014). Strategi-Strategi Pembelajaran: Bandung. Alfabeta.

Sanjaya, A. (2011). Model-model Pembelajaran. Bumi Aksara. Jakarta

Wena, M. (2013). Strategi Pembelajaran Inovatif Kontemporer. Jakarta: Buku Aksara. 